\title{
Tolpyralate Applied Alone and With Atrazine for Weed Control in Corn
}

\author{
O. Adewale Osipitan ${ }^{1}$, Jon E. Scott ${ }^{1} \&$ Stevan Z. Knezevic ${ }^{1}$ \\ ${ }^{1}$ Northeast Research and Extension Center, Haskell Agricultural Laboratory, University of Nebraska-Lincoln, \\ Concord, NE, USA \\ Correspondence: Stevan Z. Knezevic, Haskell Agricultural Laboratory, University of Nebraska-Lincoln, \\ Concord, NE, USA. Tel: 1-402-584-3810. Email: sknezevic2@unl.edu
}

$\begin{array}{lc}\text { Received: June 27, 2018 } & \text { Accepted: July 29, } 2018 \quad \text { Online Published: September 15, } 2018 \\ \text { doi:10.5539/jas.v10n10p32 } & \text { URL: https://doi.org/10.5539/jas.v10n10p32 }\end{array}$

\begin{abstract}
Tolpyralate, an HPPD (4-hydroxyphenyl-pyruvate dioxygenase) inhibitor, is a relatively new herbicide for weed control in corn. Field studies were conducted in 2015 and 2016 to evaluate the effective dose of tolpyralate applied alone or mixed with atrazine for weed control in corn. The treatments included seven rates $(0,5,20,29$, 40,50 and $\left.100 \mathrm{~g}_{\text {ai ha }}{ }^{-1}\right)$ of tolpyralate applied alone or mixed with a constant rate $\left(560 \mathrm{~g}_{\text {ai ha }}{ }^{-1}\right)$ of atrazine. The evaluated weed species were common waterhemp (Amaranthus rudis Sauer), common lambsquarters (Chenopodium album L.), velvetleaf (Abutilon theophrasti Medik), henbit (Lamium amplexicaule L.) and green foxtail (Setaria viridis L.). Overall, POST-application of tolpyralate resulted in $42-100 \%$ visual weed control, depending on the weed species and tolpyralate doses. Calculated dose of $19-31 \mathrm{~g}^{-1} \mathrm{ha}^{-1}\left(\mathrm{ED}_{90}\right)$ of tolpyralate applied alone provided $90 \%$ visual control of common waterhemp, common lambsquarters, henbit, and velvetleaf. However, addition of atrazine significantly reduced the required dose of tolpyralate to $11-17 \mathrm{~g}$ ai ha ${ }^{-1}$ for the same level of control of these weed species; suggesting a synergy between the two herbicides.
\end{abstract}

Keywords: corn, effective dose, HPPD, herbicide, tolpyralate, weeds

\section{Introduction}

There is an increase in minimum and no-till systems in United States, which in reality depends heavily on herbicides as the main tool for weed control in corn (Heap \& Duke, 2018). Due to widespread and repeated use of herbicides, weed species have developed resistance to most commonly used herbicides. A more recent example is the increase weed resistance to glyphosate. Glyphosate alone accounts for at least $35 \%$ of 86 million liters of herbicides used for pre- and post-emergence weed control in corn due to commercialization of glyphosate-tolerant (GT) corn in United States (Livingston et al., 2016). As of 2017, 17 weed species have been confirmed resistant to glyphosate across United States, of which at least 6 are present in Nebraska alone (Heap, 2017).

Diversifying the use of herbicides by incorporating alternative modes of action for weed control in general and for managing herbicide resistant weeds in particular have been widely recommended (Owen, 2016; Lamichhane et al., 2017; Osipitan \& Dille, 2017). Tolpyralate, an HPPD (4-hydroxyphenyl-pyruvate dioxygenase) inhibitor is a relatively new post-emergence herbicide for weed control in corn (Kikugawa et al., 2015; Morris et al., 2018). This new active ingredient blocks biosynthesis of carotenoids in plants through inhibition of HPPD enzyme resulting in the disruption of photosynthesis followed by death of sensitive plants (Kikugawa et al., 2015). Tolpyralate can be used as part of a diverse weed control program with herbicides of other modes of action. For example, a tank mix of tolpyralate with commonly used herbicides such as chloro-acetamides, dicamba, glyphosate and glufosinate provided excellent weed control (Tonks et al., 2015). In comparison to other HPPD-inhibitors, POST-application of tolpyralate provided weed control equal to or better than mesotrione, topramazone and tembotrione (Tonks, 2016). Currently, information is lacking on the effectiveness of tolpyralate applied alone or in mixture with atrazine for weed control in corn.

Atrazine has been the cornerstone of chemical weed control in corn for over 40 years. Atrazine has been known to improve efficacy of several HPPD-inhibiting herbicides (Abendroth et al., 2006; Kohrt \& Sprague, 2017). Therefore, the objective of this study was to determine the effective dose of one of the newest HPPD herbicide, tolpyralate, applied alone or mixed with atrazine for control of selected weed species in corn. 


\section{Materials and Methods}

\subsection{Site Description}

The experiments were conducted in 2015 and 2016 at the Haskell Agricultural Laboratory of the University of Nebraska-Lincoln in Concord, NE $\left(42.37^{\circ} \mathrm{N}, 96.68^{\circ} \mathrm{W}\right)$. The soil type of the experimental sites was Kennebec series silty clay loam (fine-silty, mixed, mesic Cumulic Hapludolls) with 0 to $2 \%$ slopes, $2.8 \%$ and $4.5 \%$ organic matter in 2015 and 2016, respectively. The soil pH was 6.3 and 5.8, respectively in 2015 and 2016. The GT corn, Pioneer 35F40 was seeded within the first week of June at moderate rate of 61,700 seeds ha ${ }^{-1}$ with row spacing of $76 \mathrm{~cm}$ apart in both years. The field tillage practice was no-till in 2015 and conventional-till in 2016. Soybean was previously cultivated on the experimental fields, with weed control mainly glyphosate-based. Total rainfall from April 1 to October 30 was $67.3 \mathrm{~cm}$ in 2015 and $61.0 \mathrm{~cm}$ in 2016. Average daily temperature was 23 and 25 ${ }^{\circ} \mathrm{C}$ in 2015 and 2016, respectively.

\subsection{Experimental Design}

The experiments were established as a randomized complete block design with 14 treatments (Table 1), in 4 replicates. The treatments include seven rates $\left(0,5,20,29,40,50\right.$ and $100 \mathrm{~g}$ ai ha $\left.{ }^{-1}\right)$ of tolpyralate applied alone or mixed with a constant rate $\left(560 \mathrm{~g}\right.$ ai ha $\left.{ }^{-1}\right)$ of atrazine. A commercial formulation of tolpyralate, ShieldEx (tolpyralate 400SC, ISK Biosciences, Concord, OH, USA) has an estimated label rate of $34 \mathrm{~g}$ ai ha ${ }^{-1}$.

The adjuvants used for all treatments were: High surfactant oil concentrate, HSOC $(0.05 \% \mathrm{v} / \mathrm{v}$, Destiny HC, WinField Solutions, Shoreview, MN, USA), and ammonium sulfate, AMS (20 g L ${ }^{-1}$, DSM Chemicals North America Inc., Augusta, GA, USA). Each of the experimental plots was $2 \mathrm{~m}$ width by $8 \mathrm{~m}$ length with five weed species seeded perpendicular to GT corn rows. The seeded weed species included common waterhemp (Amaranthus rudis L.), common lambsquarters (Chenopodium album), green foxtail (Setaria viridis), velvetleaf (Abutilon theophrasti), and henbit (Lamium amplexicaule) (Azlin Seed Service, Leland, MS, USA). The weed species were seeded with push planters $76 \mathrm{~cm}$ apart 4 days before planting the GT corn. Treatments were applied post-emergence of corn at V3 stage ( $\sim 3$ weeks after planting), while weeds were 9 to $13 \mathrm{~cm}$ tall. Herbicide applications were made using a $\mathrm{CO}_{2}$-pressurized backpack boom sprayer calibrated to deliver $140 \mathrm{~L} \mathrm{ha}^{-1}$ at 276 $\mathrm{kPa}$ through four 110015-VP flat spray nozzle tips (Turbo TeeJet, Spraying systems Co., P.O. Box 7900, Wheaton, IL 60187) with a boom length of $2 \mathrm{~m}$.

\subsection{Data Collection}

Visually rated weed control on the scale of 0 (no injury) to $100 \%$ (dead plant) were collected at $7,14,21,30$ and 60 days after treatment (DAT). The visual rating was based on symptoms such as bleaching, chlorosis, and necrosis compared to untreated control. Weed biomass was also collected within $0.25 \mathrm{~m}^{2}$ quadrant at 60 DAT. Corn was harvested from two middle rows of each plot in October each year, utilizing a combine (Almaco SP40, Nevada, IA, USA) with yield reported at $15 \%$ moisture.

\subsection{Data Analysis}

Analysis of variance was conducted to test for interaction between treatment and year of study using PROC GLM procedure in SAS 9.4 software (SAS Institute Inc, 100 SAS Campus Dr, Cary, NC 27513). A four-parameter log-logistic regression model was used to analyze the relationship between herbicide rates, and visual weed control, weed biomass or corn yield (Knezevic et al., 2007):

$$
\mathrm{Y}=\mathrm{C}+\left\{\frac{(\mathrm{D}-\mathrm{C})}{1+\exp [\mathrm{B}(\log \mathrm{X}-\log \mathrm{E})]}\right\}
$$

where, $Y$ was the visual weed control, weed biomass or corn yield, $C$ was the lower limit, $D$ was the upper limit, $X$ was the rate of tolpyralate, $E$ was the effective dose (ED50) of tolpyralate that provides a $50 \%$ visual control or weed reduction, and $B$ is the slope around $E$.

The $\mathrm{ED}_{90}$ values (dose that provided $90 \%$ weed control or biomass reduction) were calculated for both tolpyralate alone and tank-mixed with atrazine and corresponding weed species (Knezevic et al., 2018). The $\mathrm{ED}_{90}$ values between the two curves (tolpyralate alone versus mixed with atrazine) were compared for statistical differences utilizing standard errors (SE). The regression analyses were conducted using R statistical software, version 3.4.1 (R Core Team, 2017).

\section{Results and Discussion}

There was no significant interaction between years and treatments on weeds and corn yield responses, thus, data from both years were combined and regression curves fit to 30 and 60 DAT observation dates for each weed 
species. There was no lack of fit (at $\alpha=0.05$ ) for all regression curves evaluated, indicating the logistic model was valid. In general, increase in tolpyralate dose resulted in higher levels of weed control (Figures 1 to 6). Furthermore, addition of atrazine also resulted in better weed control, suggesting potential synergy between tolpyralate and atrazine. Finally, the calculated $\mathrm{ED}_{90}$ values derived from the visually rated weed control were generally similar to those derived from the weed biomass reduction based on their standard errors (Table 1).
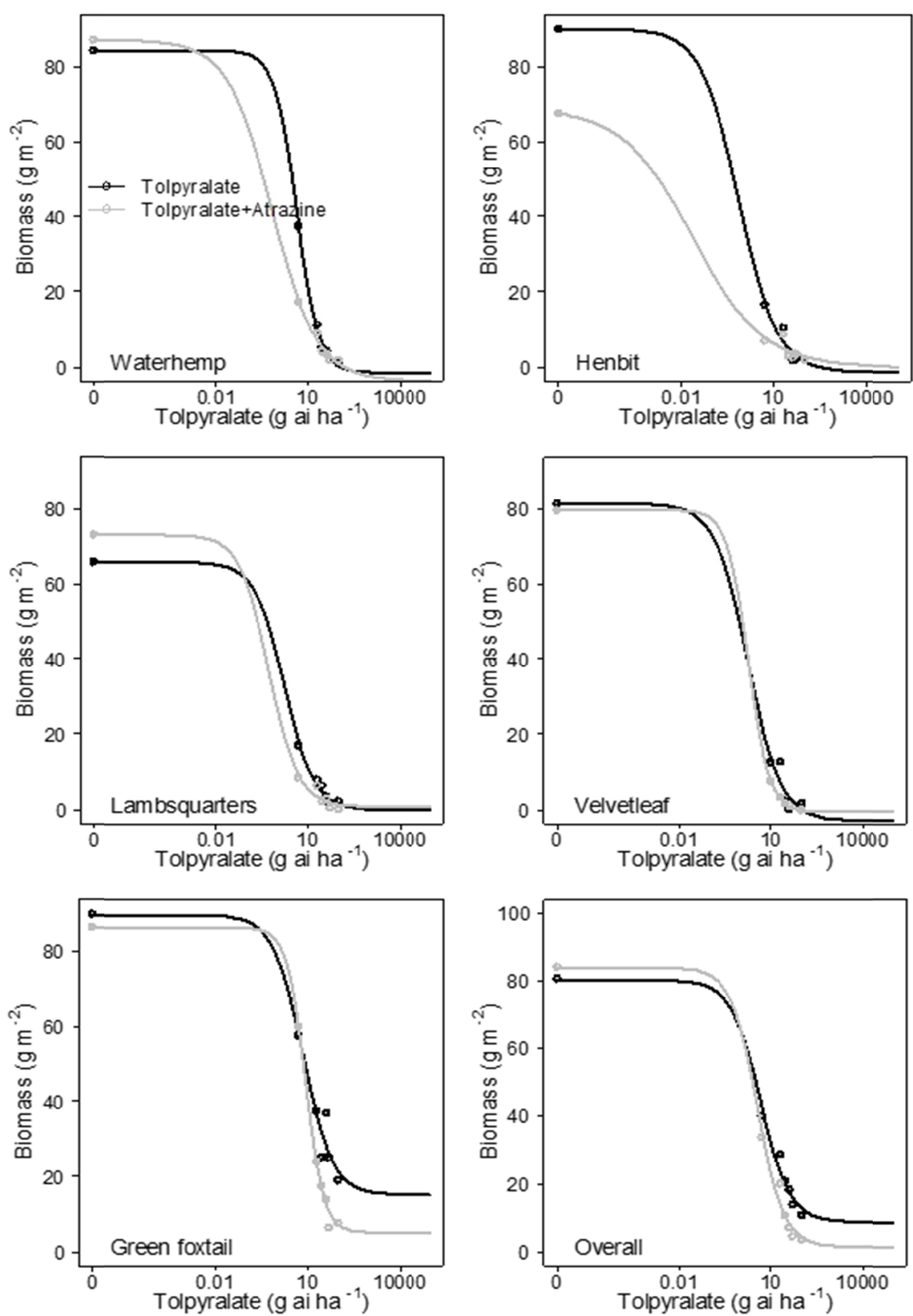

Figure 1. Dose response of weed species biomass to tolpyralate applied alone or in mixture with a constant rate

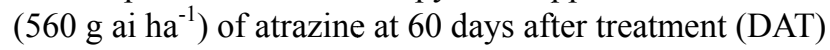


Table 1. Tolpyralate doses $\left(\mathrm{g}_{\text {ai }} \mathrm{ha}^{-1}\right)$ that provided $90 \%$ biomass reduction and visual weed control $\left(\mathrm{ED}_{90}\right)$ at 30 and 60 days after treatment (DAT)

\begin{tabular}{|c|c|c|c|c|}
\hline \multirow{2}{*}{ Weed species } & \multirow{2}{*}{ Tolpyralate } & \multirow{2}{*}{ DAT } & Biomass & Control \\
\hline & & & \multicolumn{2}{|c|}{$\mathrm{ED}_{90}( \pm \mathrm{SE})\left(\mathrm{g}\right.$ ai ha $\left.{ }^{-1}\right)$} \\
\hline \multirow[t]{4}{*}{ Common waterhemp } & Alone & 30 & - & $28(4.8)$ \\
\hline & & 60 & $27(5.8)^{\mathrm{a}}$ & $31(5.1)$ \\
\hline & With atrazine & 30 & - & $12(4.3)$ \\
\hline & & 60 & $13(5.1)$ & $16(3.8)$ \\
\hline \multirow[t]{2}{*}{ Henbit } & Alone & 60 & $17(3.2)$ & $19(3.0)$ \\
\hline & With atrazine & 60 & $7(4.5)$ & $11(2.9)$ \\
\hline \multirow[t]{2}{*}{ Common lambsquarters } & Alone & 60 & $20(3.6)$ & $20(4.1)$ \\
\hline & With atrazine & 60 & $10(3.3)$ & $11(3.1)$ \\
\hline \multirow[t]{4}{*}{ Velvetleaf } & Alone & 30 & - & $24(4.2)$ \\
\hline & & 60 & $27(8.6)$ & $27(6.4)$ \\
\hline & With atrazine & 30 & - & $17(1.4)$ \\
\hline & & 60 & $12(2.1)$ & $15(3.2)$ \\
\hline \multirow[t]{4}{*}{ Green foxtail } & Alone & 30 & - & $51(11.4)$ \\
\hline & & 60 & $52(10.2)$ & $54(7.2)$ \\
\hline & With atrazine & 30 & - & $36(8.4)$ \\
\hline & & 60 & $37(9.1)$ & $31(6.5)$ \\
\hline \multirow[t]{4}{*}{ Overall } & Alone & 30 & - & $33(6.8)$ \\
\hline & & 60 & $34(6.1)$ & $37(4.2)$ \\
\hline & With atrazine & 30 & - & $21(3.2)$ \\
\hline & & 60 & $22(5.4)$ & $29(2.3)$ \\
\hline
\end{tabular}

Note. - not evaluated; ${ }^{\text {a }}$ Means were separated using the standard errors (SE).
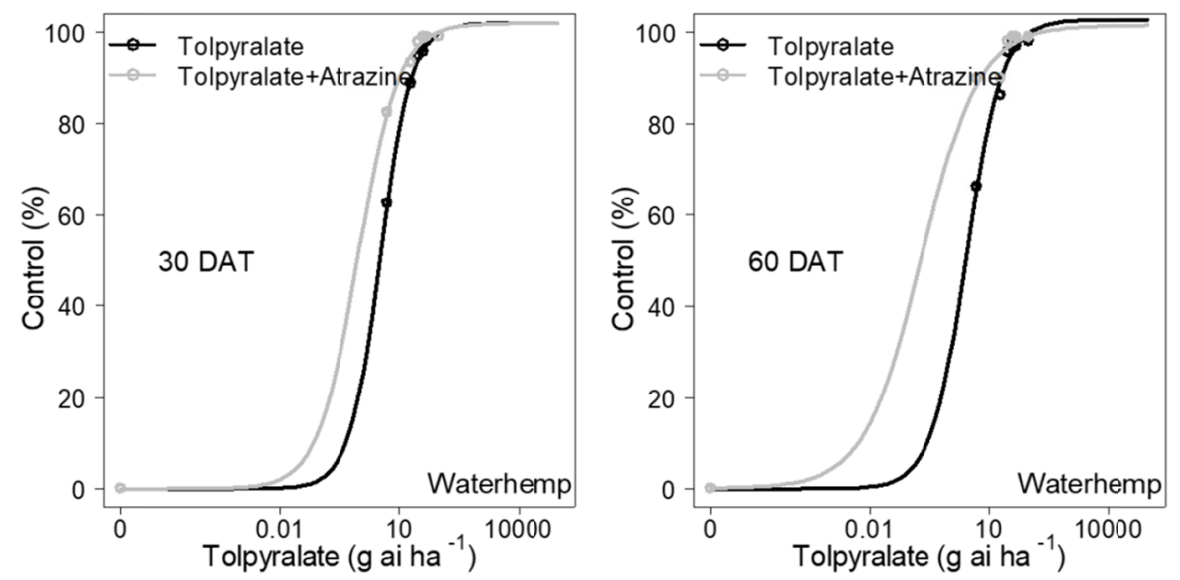

Figure 2. Dose response of common waterhemp to tolpyralate applied alone or in mixture with a constant rate $\left(560 \mathrm{~g}\right.$ ai ha $\left.{ }^{-1}\right)$ of atrazine at 30 and 60 days after treatment (DAT).

\subsection{Common Waterhemp Control}

Tolpyralate applied alone provided $65-100 \%$ visual control of common waterhemp as application rate increased from 5-100 $\mathrm{g}$ ai ha ${ }^{-1}$ at 30 DAT (Figure 2). The calculated effective dose for $90 \%$ visual control $\left(\mathrm{ED}_{90}\right)$ of tolpyralate applied alone was $28 \mathrm{~g}_{\text {ai ha }}{ }^{-1} 30$ DAT (Table 1). This dose was $31 \mathrm{~g} \mathrm{ai} \mathrm{ha}^{-1}$ for the same level of control that lasted 60 DAT. When each tolpyralate rates was mixed with a constant rate $\left(560 \mathrm{~g}\right.$ ai ha $\left.{ }^{-1}\right)$ of atrazine, visual control of common waterhemp was improved. With this mixture, the $\mathrm{ED}_{90}$ value of tolpyralate was significantly reduced from 28 to $16 \mathrm{~g}^{\text {ai }} \mathrm{ha}^{-1}$ at 30 and 60 DAT, respectively; suggesting that atrazine significantly enhanced the efficacy of tolpyralate on waterhemp control. Hausman et al. (2016) reported 
improved common waterhemp control with a tank mix of mesotrione (an HPPD-inhibiting herbicide) and atrazine, than when mesotrione was applied alone. Similar trend was observed with weed biomass data. The calculated ED value of tolpyralate for $90 \%$ reduction in common waterhemp biomass was 27 and $13 \mathrm{~g}^{\text {ai ha }}{ }^{-1}$ when applied alone and mixed with atrazine, respectively. These ED values were statistically similar to those estimated for visual waterhemp control as indicated by their standard errors (Table 1).
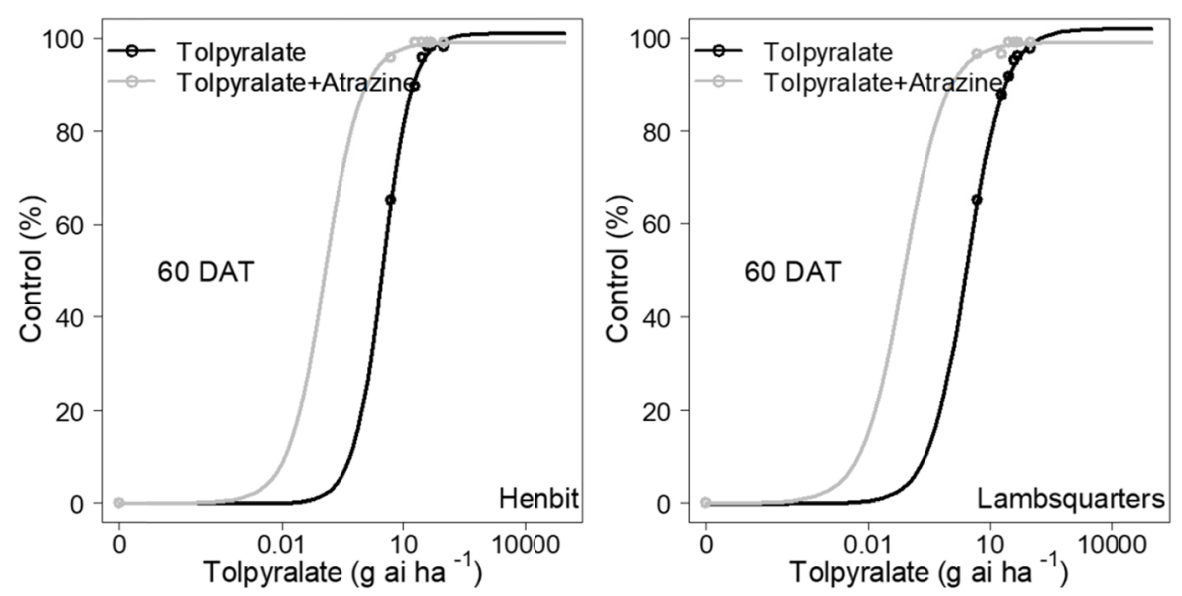

Figure 3. Dose response of henbit and common lambsquarters to tolpyralate applied alone or in mixture with a constant rate $\left(560 \mathrm{~g}\right.$ ai ha $\left.{ }^{-1}\right)$ of atrazine at 60 days after treatment (DAT)

\subsection{Henbit and Common Lambsquarters Control}

Tolpyralate provided $64-100 \%$ visual control of common lambsquaters and henbit with increasing rate from 5-100 $\mathrm{g}_{\text {ai }} \mathrm{ha}^{-1}$ when applied alone and the control lasted 60 DAT (Figure 3). The calculated ED 90 values of tolpyralate applied alone was 19 and $20 \mathrm{~g}$ ai ha ${ }^{-1}$ respectively for henbit and common lambsquarters 60 DAT (Table 1). A mixture of tolpyralate with atrazine reduced the $\mathrm{ED}_{90}$ dose for henbit and lamsquarters to $11 \mathrm{~g}$ ai ha ${ }^{-1}$, suggesting that atrazine improved the efficacy of tolpyralate for both weeds. A similar trend occurred for calculated $\mathrm{ED}_{90}$ values obtained with weed biomass reduction (Table 1). Bollman et al. (2008) reported excellent $(\geq 90 \%)$ control of common lambsquarters with HPPD-herbicides; mesotrione, tembotrione and topramezone.
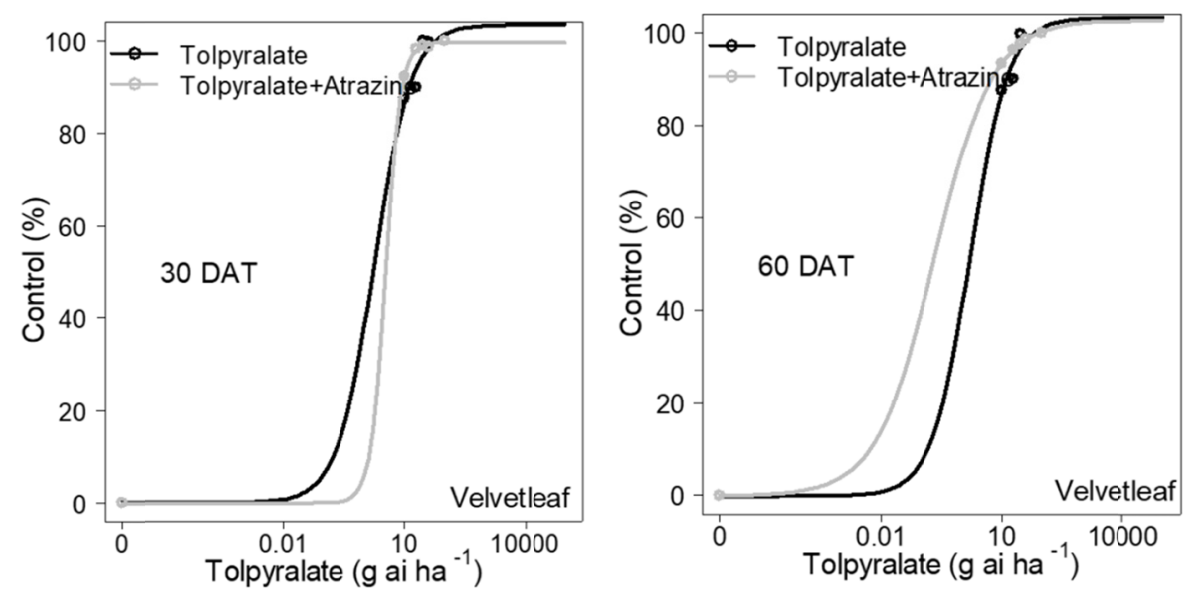

Figure 4. Dose response of velvetleaf to tolpyralate applied alone or in mixture with a constant rate $\left(560 \mathrm{~g}^{\mathrm{i}} \mathrm{ha}^{-1}\right)$ of atrazine at 30 and 60 days after treatment (DAT)

\subsection{Velvetleaf Control}

The $\mathrm{ED}_{90}$ values based on visual velvetleaf control with tolpyralate applied alone were 24 and $27 \mathrm{~g}^{\text {ai ha }} \mathrm{a}^{-1}$ for 30 and 60 DAT, respectively (Table 1). Addition of atrazine significantly reduced the $\mathrm{ED}_{90}$ value to $15 \mathrm{~g}^{\text {ai }} \mathrm{ha}^{-1}$ 
estimated at 60 DAT. Similar to previous species, these results suggested a positive impact of atrazine on tolpyralate activity on velvetleaf control. Lamore et al. (2006) and Tonks et al. (2015) had previously reported excellent $(\geq 90)$ control of velvetleaf with HPPD-inhibiting herbicides. Similar to visual data, the calculated ED value of tolpyralate for $90 \%$ reduction in velvetleaf biomass was $27 \mathrm{~g} \mathrm{ai} \mathrm{ha}^{-1}$ when applied alone. The addition of atrazine, reduced tolpyralate to significantly lower rate of $12 \mathrm{~g}$ ai ha $^{-1}$, for the same level of biomass reduction at 60 DAT.

\subsection{Green Foxtail Control}

Tolpyralate provided relatively lower visual control of green foxtail compared to broadleaf weeds, including: common waterhemp, henbit, common lambsquarters and velvetleaf. Tolpyralate applied alone, provided $40-81 \%$ visual control of green foxtail (Figure 5). The $\mathrm{ED}_{90}$ of tolpyralate applied alone was 50 and $54 \mathrm{~g} \mathrm{ai} \mathrm{ha}^{-1}$ for green foxtail control that lasted 30 and $60 \mathrm{DAT}$, respectively (Table 1). Addition of atrazine significantly reduced $\mathrm{ED}_{90}$ of tolpyralate to 36 and $31 \mathrm{~g}$ ai ha $^{-1}$ at 30 and 60 DAT, respectively. A similar trend occurred for $\mathrm{ED}_{90}$ values based on green foxtail biomass reduction. Others also reported that other HPPD-inhibiting herbicide provided relatively lower control of grasses compared to broadleaf weeds (Bollman et al., 2008; Kaastra et al., 2008).
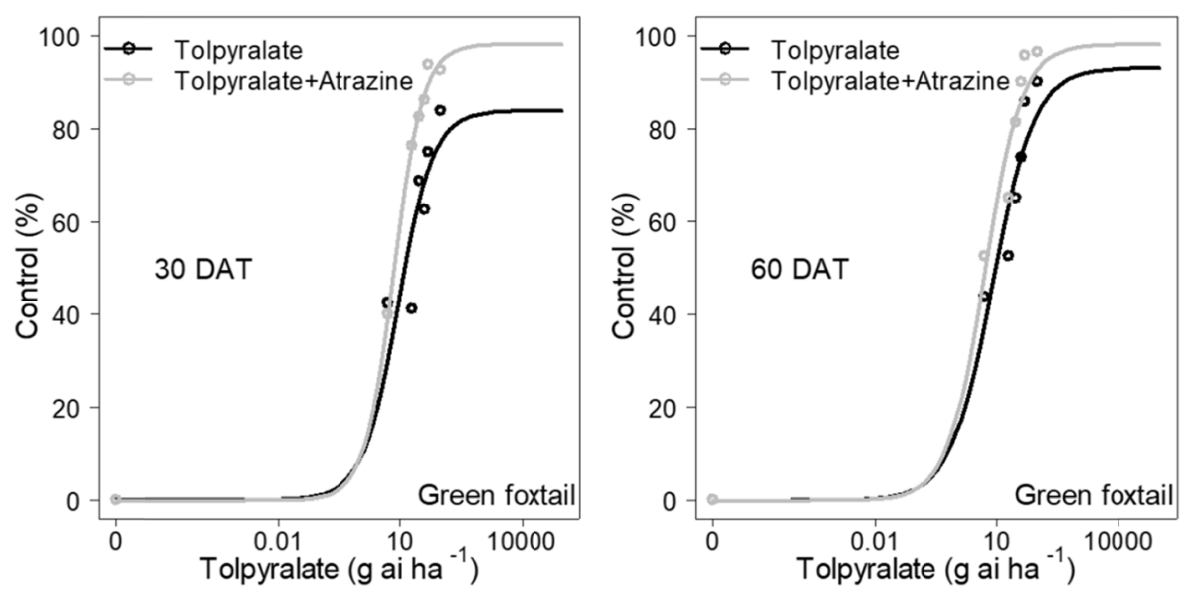

Figure 5. Dose response of green foxtail to tolpyralate applied alone or in mixture with a constant rate $\left(560 \mathrm{~g}\right.$ ai ha $\left.{ }^{-1}\right)$ of atrazine at 30 and 60 days after treatment (DAT)

\subsection{Corn Yield Response}

There was no visible injury on the GT corn by any of the tested rates (5-100 $\mathrm{g}$ ai ha $\left.{ }^{-1}\right)$ of tolpyralate, confirming that corn can metabolize tolpyralate into inactive compounds without causing any injury (Tonks et al., 2015). Other studies have also shown good corn tolerance to HPPD herbicides such as mesotrione, tembotrione and topramezone (Grossmann \& Ehrhardt, 2007; Woodyard et al., 2009; Steckel et al., 2015). The average corn yield in the season-long weedy plots was $3968 \mathrm{~kg} \mathrm{ha}^{-1}$ while the maximum yield in weed free plots was $10,872 \mathrm{~kg} \mathrm{ha}^{-1}$. Generally, all rates of tolpyralate applied alone or tank-mixed with atrazine significantly increased corn yield (Figure 6). When applied alone, tolpyralate provided yield increase as much as $52 \%$ compared to the untreated control (Figure 6). When mixed with atrazine, tolpyralate increased corn yield by as much as $61 \%$. Tolpyralate rate of $36( \pm 3.2) \mathrm{g}_{\text {ai }} \mathrm{ha}^{-1}$ applied alone was needed to maintain yield at $95 \%$ level of the weed free yield. This rate was consistent with overall $90 \%$ weed control provided by tolpyralate applied alone. When mixed with atrazine, the required rate of tolpyralate to achieve the same yield level was statistically lower (e.g. $28( \pm 2.6) \mathrm{g}$ ai $\mathrm{ha}^{-1}$ ), suggesting that atrazine synergized tolpyralate in protecting corn yield. 


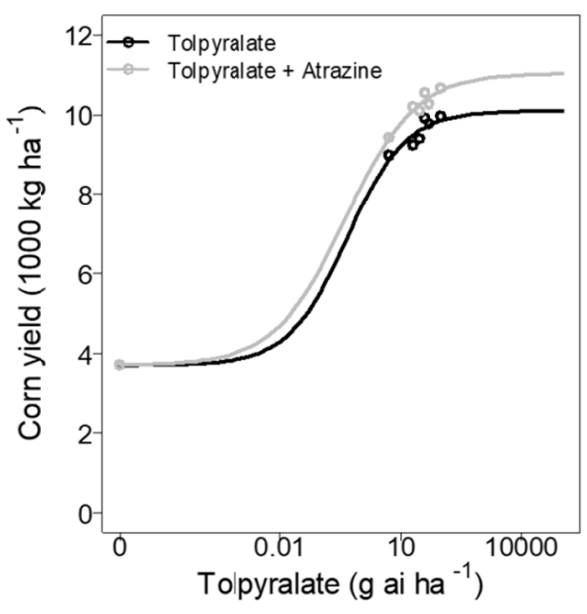

Figure 6. Corn yield $\left(\mathrm{kg} \mathrm{ha}^{-1}\right)$ as influenced by various rates of tolpyralate applied alone or in mixture with a constant rate $\left(560 \mathrm{~g} \mathrm{ai} \mathrm{ha}^{-1}\right)$ of atrazine. A four-parameter log-logistic regression model estimated the rate of tolpyralate required to achieve $95 \%$ corn yield as $36( \pm 3.2)$ and $28( \pm 2.6) \mathrm{g}$ ai ha $^{-1}$ for tolpyralate alone and tolpyralate with atrazine respectively

\section{Conclusion}

Our results indicated that the required doses of tolpyralate for excellent $(90 \%)$ control of most tested weed species were within the recommended label rate of $34 \mathrm{~g}_{\text {ai }} \mathrm{ha}^{-1}$. We confirmed also that tolpyralate efficacy can be improved when tank-mixed with atrazine. It was also previously reported that tolpyralate was tank-mixed with glyphosate, dicamba, glufosinate, and chloro-acetamides (Tonks et al., 2015), suggesting that tolpyralate can be used as part of a diverse weed control program with herbicides of other modes of action.

\section{References}

Abendroth, J. A., Martin, A. R., \& Roeth, F. W. (2006). Plant response to combinations of mesotrione and photosystem II inhibitors. Weed Technol., 20, 267-274.

Bollman, J. D., Boerboom, C. M., Becker, R. L., \& Fritz, V. A. (2008). Efficacy and tolerance to HPPD-inhibiting herbicides in sweet corn. Weed Technol., 22, 666-674. https://doi.org/10.1614/ WT-08-036.1

Grossmann, K., \& Ehrhardt, T. (2007). On the mechanism of action and selectivity of the corn herbicide topramezone: A new inhibitor of 4-hydroxyphenylpyruvate dioxygenase. Pest Manag Sci., 63, 429-439. https://doi.org/10.1002/ps.1341

Hausman, N. E., Tranel, P. J., Riechers, D. E., \& Hager, A. G. (2016). Responses of a waterhemp (Amaranthus tuberculatus) population resistant to HPPD-inhibiting herbicides to foliar-applied herbicides. Weed Technol., 30, 106-115. https://doi.org/10.1614/WT-D-15-00098.1

Heap, I. (2017). The international survey of herbicide resistant weeds. Corvallis (OR): Ian Heap.

Heap, I., \& Duke, S. O. (2018). Overview of glyphosate resistant weeds worldwide. Pest Manag Sci., 74, 1040-1049. https://doi.org/10.1002/ps.4760

Kaastra, A. C., Swanton, C. J., Tardif, F. J., \& Sikkema, P. H. (2008). Two-way performance interactions among $\rho$-hydroxyphenylpyruvate dioxygenase- and acetolactate synthase-inhibiting herbicides. Weed Sci., 56, 841-851.

Kikugawa, H., Satake, Y., Tonks, D. J., Grove, M., \& Tsukamoto, M. (2015). Tolpyralate (SL-573): A new post-emergence herbicide for weed control in corn. $55^{\text {th }}$ Annual Meeting of Weed Science Society of America, Lexington, KY, USA, Abstract 275.

Knezevic, S. Z., Osipitan, O. A., \& Scott, J. E. (2018). Sensitivity of grape and tomato to micro-rates of dicamba-based herbicides. J. Hortic., 5, 1-5. https://doi.org/10.4172/2376- 0354.1000229

Knezevic, S. Z., Streibig, J. C., \& Ritz, C. (2007). Utilizing R software package for dose-response studies: the concept and data analysis. Weed Technol., 21, 840-848. https://doi.org/10.1614/WT-06-161.1 
Kohrt, J. R., \& Sprague, C. L. (2017). Response of a multiple-resistant Palmer amaranth (Amaranthus palmeri) population to four HPPD-inhibiting herbicides applied alone and with atrazine. Weed Sci., 65, 534-545. https://doi.org/10.1017/wsc.2017.28

Lamichhane, J. R., Devos, Y., Beckie, H. J., Owen, M. D., Tillie, P., Messéan, A., \& Kudsk, P. (2017). Integrated weed management systems with herbicide-tolerant crops in the European Union: Lessons learnt from home and abroad. Crit Rev Biotechnol., 37, 459- 475. https://doi.org/10.1080/07388551.2016.1180588

Lamore, D., Simkins, G., Watteyne, K., \& Allen, J. (2006). Weed control programs with tembotrione in corn. Proc. North Central Weed Science Society, 61, 119.

Livingston, M., Fernandez-Cornejo, J. \& Frisvold, G. B. (2016). Economic returns to herbicide resistance management in the short and long run: The role of neighbor effects. Weed Sci., 64, 595-608. https://doi.org/10.1614/WS-D-15-00047.1

Morris, J. A., Boehmer, J. E., Whittingham, W. G., Desson, T. R., Dalencon, A. J., Pickett, B., et al. (2018). U.S. Patent Application No. 15/562,652.

Osipitan, O. A., \& Dille, J. A. (2017). Fitness outcomes related to glyphosate resistance in kochia (Kochia scoparia): What life history stage to examine? Front. Plant Sci., 7, 1-13. https://doi.org/10.3389/fpls.2017. 01090

Owen, M. D. (2016). Diverse approaches to herbicide-resistant weed management. Weed Sci. 64: 570-584. https://doi.org/10.1614/WS-D-15-00117.1

R Core Team. (2017). R: A language and environment for statistical computing. R Foundation for Statistical Computing, Vienna, Austria.

SAS (Statistical Analysis Systems). (2017). SAS System Windows, Release 9.4 (p. 955). Cary, NC: Statistical Analysis Systems Institute.

Steckel, L. E., Stewart, S. D., \& Steckel, S. (2015). Corn response to post-applied HPPD-inhibitor based premix herbicides with in-furrow and foliar-applied insecticides. Weed Technol., 29, 18-23. https://doi.org/10.1614/ WT-D-14- 00030.1

Tonks, D. J. (2016). Weed Control efficacy in corn on common annual weeds in the United States. $56^{\text {th }}$ Annual Meeting of Weed Science Society of America, Lexington, KY, USA, Abstract 424.

Tonks, D. J., Grove, M., Kikugawa, H., Parks, M., Nagayama, S., \& Tsukamoto, M. (2015). Tolpyralate (SL-573): An overview of performance for weed control in corn in the U.S. $55^{\text {th }}$ Annual Meeting of Weed Science Society of America, Lexington, KY, USA, Abstract 276.

Woodyard, A. J., Bollero, G. A., \& Riechers, D. E. (2009). Broadleaf weed management in corn utilizing synergistic postemergence herbicide combinations. Weed Technol., 23, 513-518. https://doi.org/10.1614/ WT-08-188.1

\section{Copyrights}

Copyright for this article is retained by the author(s), with first publication rights granted to the journal.

This is an open-access article distributed under the terms and conditions of the Creative Commons Attribution license (http://creativecommons.org/licenses/by/4.0/). 